\title{
„Lepiej nie mówić” Milczenie ofiar gwałtów wojennych z okresu drugiej wojny światowej w relacjach świadkiń
}

\author{
"Better Left Untold" \\ The Silence of World War II Rape Victims in Female Witnesses' Accounts
}

\begin{abstract}
Aвstract: "Better left untold", “There was no opportunity", "I wanted to talk about it, but there was no one to talk to" - these are the most frequently occurring statements by female witnesses and victims of sexual violence during World War II. They also repeatedly crop up in accounts of rape victims during other military conflicts in the XX century. In the narratives, the most frequent statements are those which attempt to repress the experiences and which communicate a fear of stigmatization. Not only was there no one who would listen; the very act of talking about "it" entailed consequences. All of the female witnesses and victims whose testimonies are analyzed in this article have drawn attention to the fear of stigmatization, especially after the War, among relatives, neighbors and other people.

The witnesses' micro-narratives are a point of departure for an analysis of rape in the last months of the War in view of the lack of victims' accounts. Why didn't the women speak out? How did they cope with the trauma of sexual violence? What eventually made them decide to speak?
\end{abstract}

KEY WORDS: war rape, World War II, silence, sexual violence, taboo

„Ja swój ból w moim życiu prawie całkowicie wyparłam, chociażby dlatego, że później też życie, jak bardzo wielu nam, stawiało inne trudne problemy do rozwiązania"" - mówi Barbara, która była ofiarą gwałtu wojennego w lutym

${ }^{1}$ Wszystkie wypowiedzi Barbary Stachowiak w tym tekście pochodzą z wywiadu przeprowadzonego w 2009 r. w Poznaniu, w domu świadkini. Wywiad poprzedziła korespondencja mailowa i adresowany do mnie list Barbary z dn. 27 marca 2009 r. 
1945 roku. Miała wtedy trzynaście lat. Została zgwałcona przez kilku żołnierzy radzieckich w Poznaniu, na pierwszym piętrze budynku, w którym mieszkała razem ze swoją rodziną. W tym jednym dniu, w jednej kamienicy w Poznaniu na ul. Łąkowej ${ }^{2}$ dokonano zbiorowego gwałtu na czterech dziewczynach. Po akcie przemocy nigdy się już nie spotkały. Barbara nie wie, kim były inne ofiary. Pamięta tylko, że była najmłodsza. Trzy pozostałe miały około osiemnaście, dziewiętnaście lat.

Kiedy w 2009 roku zapytałam Barbarę, dlaczego tak długo milczała, odpowiedziała mi krótko: „Większość ludzi, których to »trafiło«, nie chciała o tym mówić. Ja też”. Barbara milczała ponad sześćdziesiąt lat. Gdyby nie publikacja tekstu autorstwa Marcina Zaremby i mojego w tygodniku „Polityka”, pewnie nigdy nie opowiedziałaby swojej historii:

Nigdy nie było „okazji”. Mijały lata i wszystko tak sobie po prostu było. Gdyby nie ten artykuł, milczałabym. Do początku lat pięćdziesiątych wszyscy bali się [o tym - J.O.] mówić. A później już powoli zapominano. Jeśli ktoś na te tematy rozmawiał, to zawsze mówił o „kimś”, a nie że „ja” [...]. Gdzieś tam, ktoś tam, coś tam słyszałam.

„Lepiej nie mówić”, „Nie było okazji”, „Chciałam o tym porozmawiać, ale z kim?” - to najczęściej powtarzające się wypowiedzi świadkiń, które były ofiarami przemocy seksualnej w czasie drugiej wojny światowej. Te zdania powielają się także w świadectwach kobiet zgwałconych w trakcie innych konfliktów zbrojnych w XX wieku. W ich opowieściach przeważają próby wyparcia i strach przed naznaczeniem ${ }^{4}$. Nie tylko nie było komu powiedzieć, ale też mówienie o „tym” wiązało się z konsekwencjami ${ }^{5}$. Wszystkie bohaterki niniejszego tekstu

${ }^{2}$ Kamienica, w której mieszkała rodzina Barbary, znajdowała się tuż obok szpitala sióstr elżbietanek na ul. Łąkowej. Od 1943 r. szpital ten nosił nazwę Bertha Spitzer Krankenhaus. Niemcy opuścili jego budynki 22 stycznia 1945 r. 3 lutego zostały one zajęte przez wojsko radzieckie. Por. A. Magowska, H. Bogusz: Z dziejów Sanatorium św. Elżbiety w Poznaniu i jego właścicielek. „Acta Medicorum Polonorum" 2014, R. 4, s. 75.

${ }^{3} 11$ marca 2009 r. Barbara Stachowiak napisała do mnie pierwszego e-maila zachęcona artykułem Kobieca gehenna. Autorzy umieścili pod nim prośbę o kontakt do kobiet, które były ofiarami przemocy seksualnej. Por. J. Ostrowska, M. Zaremba: Kobieca gehenna. „Polityka” 2009, nr 10 (2695), s. 64-66.

${ }^{4}$ Por. S. Eichhorn, Ph. Kuwert: Das Geheimnis unseres Großmütter. Eine empirische Studie über sexualisierte Kriegsgewalt um 1945. Gießen 2011.

${ }^{5}$ Jako jedna z pierwszych temat gwałtów wojennych w okresie drugiej wojny światowej sproblematyzowała Susan Brownmiller (1975). Na polskim gruncie badawczym warto zwrócić uwagę na książki Joanny Hytrek-Hryciuk i Marcina Zaremby. Por. S. Brownmiller: Against Our Will. Men, Women and Rape. New York 1993; J. Hytrek-Hryciuk: „Rosjanie nadchodza!”. Ludność niemiecka a żolnierze Armii Radzieckiej (Czerwonej) na Dolnym Śląsku w latach 1945-1948. Wrocław 2010; M. Zaremba: Wielka Trwoga. Polska 1944-1947. Ludowa reakcja na kryzys. Kraków 2012; M. Gebhardt: Crimes Unspoken: The Rape of German Women at the End of the Second World War. Transl. N. Somers. Cambridge 2017. 
zwracały uwagę na strach przed stygmatyzacją, szczególnie po wojnie - wśród bliskich, sąsiadów, osób postronnych.

Barbara, Alaine, Zofia i Anna milczały przez lata, wypierając doświadczenie gwałtu wojennego. Niektóre z nich nie odważyły się mówić. Historie innych zachowały się tylko na kartach powojennych dokumentów świadczących mocniej o tym, jak łatwo potrafiono zlekceważyć ofiary. Biografia części z tych kobiet zachowała się tylko w strzępach opowiadających o aktach przemocy. Nie wiemy nic więcej na temat ich powojennych doświadczeń. W każdym przypadku sprawcom chodziło o zemstę i zaznaczenie władzy nad słabszą jednostką. Byli to nie tylko żołnierze Armii Czerwonej, ale także Polacy - „wymierzający sprawiedliwość" na zdrajczyniach: Niemkach.

Tekst postanowiłam rozpocząć od historii Barbary Stachowiak, ponieważ zachowane świadectwo to relacja ustna (oral history) - kobieta nie odpowiadała w nim na pytania organów ścigania, które często formatowały i odczłowieczały doświadczenie ofiar, ale sama decydowała o tym, co chciałaby powiedzieć o akcie przemocy seksualnej. Jednocześnie spotkanie z Barbarą bardzo mocno wpłynęło na moje nastawienie badawcze - jej głos utwierdził mnie w przekonaniu, że warto walczyć o destygmatyzację ofiar i odtabuizowanie omawianego procederu'

Opowieść Alaine Polcz to dokument osobisty spisany w formie autobiografii i wydany na początku lat 90 . XX wieku. Tymczasem Zofia Lamparska i Anna Ewald zeznawały w powojennym śledztwie - ich relacje, już choćby ze względów formalnych, są więc "niepełne”. Dla sądu ważne było jedynie to, żeby zeznania te doprowadziły do skazania komendanta obozu. Trauma kobiet była nieistotna, liczył się sam akt złamania prawa.

Dla bohaterek tego tekstu okres między lutym a lipcem 1945 roku stał się czasem niewyobrażalnego cierpienia, o którym po prostu „nie wypadało” nikomu powiedzieć, bo i nie o cierpienie tu chodziło. Tak zresztą było łatwiej.

W Niemczech od początku 2008 roku zespół psychologów zajmował się stresem pourazowym (PTSD) wśród kobiet, które doświadczyły gwałtu wojennego $\mathrm{w}$ trakcie drugiej wojny światowej ${ }^{7}$. W ciągu kilku lat przebadano prawie trzydzieści kobiet, które $\mathrm{w}$ trakcie przestępstwa miały od 12 do 25 lat $-75 \%$ z nich uznało gwałt wojenny za najgorsze doświadczenie w swoim życiu. Tylko siedem kobiet kiedykolwiek próbowało rozmawiać na ten temat $\mathrm{z}$ innymi osobami. Reszta wypierała przemoc seksualną, koncentrując się na pracy, religii, rodzinie. Ponad $80 \%$ badanych miało problemy ze swoją seksualnością. Gwałt wpłynął w znaczący sposób na ich życie rodzinne i relacje z przyjaciółmi. Część z nich

${ }^{6}$ Ten wywiad stał się inspiracją do napisania książki, por. J. Ostrowska: Przemilczane. Seksualna praca przymusowa w czasie II wojny światowej. Warszawa 2018.

${ }^{7}$ Por. S. Eichhorn, Ph. Kuwert: Das Geheimnis unseres Großmütter... 
kilkadziesiąt lat po wojnie nie umiała opanować wściekłości spowodowanej tym, co się stało.

Wszystkie kobiety występowały pod pseudonimami. Nie ujawniono ich danych osobowych. Siedemdziesięciosześcioletnia I. S., zapytana o powojenne milczenie, odpowiedziała: „W czasach wojny jedno przychodziło po drugim. Człowiek przeżył tak wiele, że zawsze, kiedy coś się działo, to było odsuwane [podkr. - J.O.], ponieważ zaraz przychodziło coś nowego"8. Na przepracowanie traumy nie było więc czasu, nawet jeśli ogrom cierpień i doświadczeń przemocowych z okresu wojny i powojnia był wręcz przytłaczający. Kobiety gwałcono wielokrotnie, a sprawcy pozostawali anonimowi. Z czasem stosunek seksualny stał się „walutą”, którą płacono za możliwość przeżycia. Nawet jeśli przemoc seksualna była upokarzająca i odciskała piętno na życiu kobiet, to stawała się też elementem codzienności.

W Polsce dwie dekady po wojnie gwałt wojenny nie był w żaden sposób sproblematyzowany. W latach 1966-1967 i 1972 Jerzy S. Giza i Wiesław Morasiewicz przeprowadzili na grupie więźniów i więźniarek badania, których celem było stworzenie pierwszej analizy zaburzeń seksualnych w grupie ofiar obozów ${ }^{9}$. Uznawano je za element tzw. KZ-syndromu. W przypadku więźniarek zbadano dwadzieścia kobiet polskiego pochodzenia ${ }^{10}$, które $\mathrm{w}$ trakcie pobytu w obozie miały od 16 do 20 lat. Próba była tak niewielka z oczywistych powodów:

Drażliwość badanej tematyki spowodowała, że tylko niewielki odsetek byłych więźniarek niemieckich obozów koncentracyjnych zdołano ogarnąć wszechstronną analizą seksuologiczną; liczne kobiety, do których zwrócono się z prośbą o udzielenie interesujących nas informacji, odpowiedziały odmownie lub nie wyraziły zgody na uczestniczenie w pełnej skali problematyki ${ }^{11}$.

Analiza obejmowała: okres przedwojenny, obozowy, poobozowy (pierwszy rok po wyzwoleniu) i czasy współczesne. Byłym więźniarkom zadawano pytania o menstruację, sny erotyczne, orgazm nocny, masturbację, kontakty homoi heteroseksualne. W analizie badań nie ma słowa o gwałtach i innych formach przemocy seksualnej. W podsumowaniu autorzy zwracali uwagę, że w wyniku doświadczeń obozowych badane kobiety cierpiały na zaburzenia zdolności do rodzenia dzieci i zdolności do prawidłowych reakcji na bodźce seksualne:

8 Tamże, s. 72. Tłumaczenie moje - J.O.

9 J.S. Giza, W. Morasiewicz: Z zagadnień popędów w obozach koncentracyjnych. Przyczynek do analiz tzw. KZ-syndromu. „Przegląd Lekarski” 1973, nr 1, s. 29-41.

${ }_{10} \mathrm{~W}$ tekście nie zaznaczono narodowości więźniarek. Zakładam, że gdyby kobiety pochodziły z różnych krajów albo deklarowały różną przynależność etniczną bądź narodową, zostałoby to zasygnalizowane. Por. J.S. Giza, W. Morasiewicz: Poobozowe zaburzenia seksualne u kobiet jako element tzw. KZ-syndromu. „Przegląd Lekarski” 1974, nr 1, s. 65-75.

11 Tamże, s. 65. 
Obie ważne funkcje seksualizmu kobiecego wśród byłych więźniarek obozów koncentracyjnych zostały naruszone bardzo poważnie. Zdolność rodzenia w stosunku do przeciętnej populacji została obniżona o przeszło 50\%, co jest wartością bardzo wysoką. Liczba badanych, które można zaliczyć do najbardziej pożądanego typu reakcji orgastycznej, tj. do orgastycznego seksualno-pozytywnego jest znikoma (5\% wobec $68 \% \mathrm{w}$ warunkach populacji przeciętnej). Jeżeli przy tym weźmiemy pod uwagę fakt, że większość spośród badanych cierpi na różne choroby somatyczne, a przeszło $60 \%$ badanych wykazuje różnorodne odchylenia od normy w zakresie zdrowia psychicznego, wtedy obraz stanu zdrowia byłych więźniarek obozów koncentracyjnych przedstawi się dramatycznie ${ }^{12}$.

W tekście Gizy i Morasiewicza nie pojawia się nawet aluzja do doświadczeń gwałtu. Powojenny brak aktywności seksualnej byłych więźniarek tłumaczono „wygaszeniem zainteresowań seksualnych w wyniku stresu obozowego"13. Przeżycia obozowe uznawane były więc za przyczynę zaburzenia o charakterze seksualnym, ale żaden $z$ badaczy nie zadał sobie pytania o to, jakiej natury były to doświadczenia i czy miały związek z seksualną przemocą. Dodatkowo okres powojenny badacze uznawali za „czas pokoju” - wolny od zagrożeń. Nikomu nie przyszło do głowy, że większość byłych więźniarek po powrocie do domu była narażona na przemoc seksualną „wyzwolicieli” ${ }^{14}$.

\section{Barbara: „Nie wolno o »tym« mówić, bo to jest coś bardzo brzydkiego"}

„Dziękuję za Pani zainteresowanie tymi bolesnymi sprawami, dziękuję za emaile otrzymane od Pani. Zdaję sobie sprawę, że Pani czas jest ograniczony, mój natomiast odwrotnie" - tak brzmiał początek listu Barbary z marca 2009 roku. Nareszcie miała czas, żeby opowiadać. Trudno było ją przekonać, że naprawdę chciałam i mogłam jej wysłuchać. Od naszego pierwszego kontaktu w marcu 2009 roku do spotkania na żywo minęło ponad pół roku. Zanim doszło do wywiadu, przeczytałam list Barbary wielokrotnie: „Spraw, o których byśmy

12 Tamże, s. 74.

13 Tamże, s. 71.

14 O gwałtach na więźniarkach FKL Ravensbrück, które wracały do Polski, opowiadały mi w wywiadach: Stanisława Jankiewicz (wywiad przeprowadzony wspólnie z T. Szwan w listopadzie 2008 r.) i Janina Kujawska-Tenner (rozmowa w maju 2010 r.; oba wywiady pochodzą z mojego archiwum). Ten temat pojawił się także w książce Zofii Posmysz: Do wolności, do śmierci, do życia. Radzymin 1996. 
mogły rozmawiać, nie da się łatwo opisać w liście, więc spróbuję podać Pani najważniejsze". Wszystko, co opowiedziała, było dla mnie bezcenne.

Pierwszy opis gwałtu pochodził z naszej korespondencji:

W tym wspomnianym dniu (4.02.1945) wtargnęli do naszego schronienia żołnierze radzieccy, szukający „germańców”. Wśród nas wszystkich wybrano 4 najmłodsze kobiety (ja byłam wysoka i dobrze rozwinięta). Pod przyłożonymi nam do pleców karabinami poprowadzono nas do opuszczonego mieszkania na pierwszym piętrze. Tam dokonali rozdzierając na nas ubranie swoich barbarzyńskich czynów. Ja chyba zemdlałam, bo dopiero po dłuższym czasie powlokłam się do schronu.

List Barbary kończył się mocną kodą: gwałt w wieku trzynastu lat wpłynął na jej życie w sposób trudny do opisania, ale - jak napisała - „nie jestem osobą zgorzkniałą. W życiu potem osiągnęłam dużo, jestem lekarką, dodatkowo pracowałam po ukończeniu szkoleń z młodzieżą i inne prace”.

Pierwsze pytanie, które zadałam świadkini w trakcie wywiadu, dotyczyło sensu prowadzenia rozmów z ofiarami przemocy seksualnej i historycznych badań związanych z tym zjawiskiem. Barbara odpowiedziała krótko: „Trzeba jeszcze zanotować to, co można, co jeszcze w ludziach pozostało”. Następnie pytałam o tabu i stygmę - czemu przemilczano zjawisko gwałtów wojennych? Barbara stwierdziła:

Być może [winna jest tu - J.O.] katolicka Polska. Ja też jestem katoliczką, ale to jest jakiś taki inny katolicyzm. Nie wolno o „tym” mówić, bo to jest coś bardzo brzydkiego, a przecież seks nie jest niczym brzydkim. Ja Pani napisałam, że ja nie doznałam przyjemności seksu, ale jestem lekarzem. Znam to ze strony lekarskiej. Większość ludzi, których to „trafiło”, nie chcieli o tym mówić. Mnie też jest trudno o tym mówić. $\mathrm{Z}$ ojcem nie mówiłam ani razu. Matka zginęła tydzień po tym wydarzeniu.

Odwołanie do katolicyzmu nie pojawiło się już później w naszej rozmowie, ale narracja bogoojczyźniana dotycząca drugiej wojny światowej bardzo mocno wpłynęła na to, jak traktowało się i traktuje nadal ofiary przemocy seksualnej w trakcie konfliktów zbrojnych.

Przede wszystkim wojenna przemoc seksualna miała na celu poniżenie i zastraszenie ofiar, ale jednocześnie niszczyła lokalne społeczności ${ }^{15}$. Gwałty wojenne traktowano jako rodzaj broni - symboliczne „pokonanie” przeciwnika

${ }^{15}$ Doris L. Bergen mówi o trzech funkcjach przemocy seksualnej w okresie drugiej wojny światowej: dehumanizowanie ofiary; zastraszanie i niszczenie lokalnych społeczności; normalizacja zbrodni. Por. D.L. Bergen: Sexual Violence in the Holocaust: Unique and Typical? In: Lessons and Legacies VII. The Holocaust in International Perspectives. Ed. D. Herzog. Evanston 2006, s. $179-200$. 
poprzez naznaczenie ciał kobiet, które stanowiły trofea. W narracji narodowej zgwałcone kobiety zostały zbrukane (Barbara wspomina o brudzie). Ich historia powinna zostać przemilczana jako przykład porażki, antybohaterstwa i braku oporu.

Ponadto $\mathrm{w}$ tradycji katolickiej bardzo żywy pozostaje kult błogosławionej Karoliny Kózki - szesnastoletniej dziewczyny, która „wybroniła się” przed gwałtem rosyjskiego żołnierza na początku pierwszej wojny światowej. Nastolatka została siłą wyciągnięta z domu i zaprowadzona do lasu:

W tym czasie dwaj kilkunastoletni chłopcy, Franciszek Zaleśny i Franciszek Broda, ukrywali konie w gęstwinie leśnej z obawy przed rekwizycją. Z odległości kilkudziesięciu kroków zobaczyli uzbrojonego żołnierza pędzącego przed sobą jakąś młodą dziewczynę, która stawiała mu opór, broniła się silnymi ciosami i usiłowała zawrócić $\mathrm{z}$ drogi. [...]

Dopiero 4 grudnia znaleziono jej zwłoki, [...]. Liczne rany mówiły wyraźnie o mężnej walce i wielkości doznanego cierpienia. W odległości około $100 \mathrm{~m}$ od zwłok znaleziono kurtkę, którą narzuciła na siebie wychodząc z domu, dalej jeden but, jeszcze dalej drugi. Ślady wskazywały na to, że dziewczyna, kilkakrotnie cięta ostrą bronią, wyrwała się w końcu żołnierzowi i uciekała w stronę wioski poprzez bagna, krzaki głogu i ostrężyn. Wyczerpana całkowicie walką, upływem krwi, bólem i ucieczką upadła na skraju lasu na trzęsawisku i tam skończyła życie ${ }^{16}$.

Ciało młodej kobiety poddano oględzinom w obecności świadków. Położna stwierdziła, że Karolina zachowała dziewictwo, które wcześniej ofiarowała Bogu. W obliczu zagrożenia „wybrała” śmierć. Relacje zgwałconych kobiet, które przeżyły, skonfrontowane $\mathrm{z}$ historią katolickiej męczennicy przestają mieć znaczenie albo wręcz stają się opowieściami o antybohaterstwie i poddaniu się sprawcy ${ }^{17}$. Na poziomie symbolicznym mamy do czynienia z narracją, w której ofiary przemocy seksualnej nie powinny przeżyć:

${ }^{16}$ S.L. Piech: Błogosławiona Karolina Kózka. „Folia Historica Cracoviensia” 2010, nr 15/16, s. 193. Osobny wątek w historii Karoliny Kózki to sposób opisu biografii tej młodej kobiety, który opiera się przede wszystkim na pozbawieniu jej cielesności, seksualności i jakiejkolwiek decyzyjności: „Nie lubiła dużo mówić, nie lubiła, gdy na nią zwracano uwagę. Cicha, nie wyróżniała się zbytnią urodą [...]. Jako dorastająca dziewczyna wyróżniała się wśród rówieśnic skromnością w postawie i w całym zachowaniu. Choć lubiła się porządnie ubrać w niedzielę, nie przywiązywała zbytniej wagi do strojów ani innych rzeczy, które pochłaniają uwagę dziewcząt w jej wieku" (tamże, s. 191, 192).

${ }_{17}$ Tematyka gwałtów wojennych jest coraz częściej wykorzystywana przez katolickie środowiska antyaborcyjne. Najlepszym przykładem tego nurtu jest książka M. Okrafki-Nędzy Bóg liczy łzy kobiet. Prawdziwa historia kobiety zgwatconej przez sowieckiego „oswobodziciela” (Warszawa 2016). Autorką posłowia do tej publikacji jest Kaja Godek. 
I oto, padając pod ręką napastnika, Karolina daje ostatnie na tej ziemi świadectwo temu życiu, które jest w niej. Śmierć cielesna go nie zniszczy. Śmierć oznacza nowy początek tego życia, które jest z Boga, które staje się naszym udziałem przez Chrystusa, za sprawą Jego śmierci i zmartwychwstania. Ginie więc Karolina. Jej martwe ciało dziewczęce pozostaje wśród leśnego poszycia. A śmierć niewinnej zdaje się odtąd głosić ze szczególną mocą tę prawdę, którą wypowiada Psalmista: „Pan jest moim dziedzictwem, Pan jest moim przeznaczeniem. To On mój los zabezpiecza" (por. Ps 16, 5). Tak. Karolina porzucona wśród lasu rudziańskiego jest bezpieczna. Jest w rękach Boga, który jest Bogiem życia [podkr. - J.O.] ${ }^{18}$.

Barbara nie pamiętała żadnych plotek o zbliżających się żołnierzach radzieckich. Nikt nie wspominał o gwałtach. Pod koniec stycznia matka powiedziała do niej tylko: „Niemcy nas okradli, a ci [Rosjanie - J.O.] nas zabiją”. Nic więcej. 4 lutego 1945 roku:

[...] wpadli [do piwnicy, gdzie chronili się ludzie - J.O.] i tak rozejrzeli się. Wyciągnęli nas na pierwsze piętro, gdzie znajdowała się część szpitala [...]. Były puste łóżka. [...] I tam nas no niestety, trzymając prawda karabiny ${ }^{19}$, zgwałcili wszystkie. Jak to się wszystko działo, to ja, prawdę mówiąc, niewiele $\mathrm{z}$ tego pamiętam. Pamiętam - nie wiem dlaczego - że było bardzo jasno, jak wróciłam do domu. A to jest niemożliwe, bo przecież prądu nie było i świeciło się jakimiś świeczkami, czy resztkami nafty. Ale ja byłam tak mocno przerażona, stąd mam wrażenie do tej pory, że ja weszłam do jakiegoś strasznie jasnego pomieszczenia. Z tamtego ciemnego, gdzie były... Wyciągnęli nas na pierwsze, czy drugie piętro i potem wróciłam do domu. I nikt się mnie o nic nie spytał. Albo tego nie pamiętam. W każdym razie miałam wrażenie jasności, jak zeszłam [do piwnicy - J.O.], parę osób stało i patrzyło na mnie z przerażeniem ${ }^{20}$.

${ }^{18}$ Jan Paweł II: Homilia w czasie Mszy św. beatyfikacyjnej Karoliny Kózkówny, 10.06.1987. Dostępne w Internecie: http://www.nauczaniejp2.pl/dokumenty/wyswietl/id/739/pos/16/haslo/ [data dostępu: 7.10.2020].

${ }_{19}$ E. L. (mieszkanka Poznania): „Łomotali w drzwi kolbami karabinów, póki ich nie otworzyłyśmy. Nie zwracając uwagi na matkę i ciotkę, które musiały wstać z łóżek, Rosjanie gwałcili mnie i siostrę, wciąż trzymając karabiny. Leżeli rozwaleni na łóżkach z brudnymi buciorami, czekając na swoją kolej. W ciemności, tylko przy świetle kieszonkowych latarek, nie widziałyśmy, jak te bestie wyglądały. Trwało to dzień i noc, bez chwili spokoju. Trudno już nawet było to nazwać gwałtem, bo kobiety były dla nich tylko biernymi instrumentami; nie dało się przed tym bronić czy odmówić, można to było tylko przecierpieć" (S. Brownmiller: Against Our Will..., s. 69. Tłumaczenie - P. Soszyński).

${ }^{20}$ Niektóre fragmenty wywiadu z Barbarą pojawiły się w filmie Anny Baumgart Świeże wiśnie (2010). 
Moment gwałtu wrócił jeszcze przy okazji rozmowy o ubraniu:

Ja byłam w [...] spodniach w kratkę z koca, które uszyła mi mama. Tu miałam jakąś bluzkę, sweterek, coś takiego, ale oni to na mnie rozdarli. Pamiętam ten moment rozdzierania. Później pamiętam, że zeszłam dwa piętra na dół i weszłam do tego naszego mieszkania, w którym było dziwnie jasno, a nie mogło być jasno, bo co najwyżej była zapalona świeczka. Potem znalazłam się w łóżku i to wszystko. I potem następnych dni też nie umiem sobie przypomnieć. Dopiero moment, jak matka poszła po wodę [...]. I za chwilę przybiegła i mówi: jestem ranna. Sąsiedzi próbowali ją opatrywać. Ja chyba nawet nie. Potem położyli ją do łóżka. Miała jakieś widzenia: „Jakiś czarny mężczyzna chce tu wejść, chce was zabrać”. Potem się budziła i mówiła tak: „Kołdrę to ty weźmiesz, a poduszka niech dla ojca zostanie. Opiekuj się bratem. Pamiętaj, nie zostawiaj go samego". Potem znowu mówiła logicznie [...]. A ojciec wtedy siedział i płakał.

Po wojnie Barbara, wraz z bratem, została przewieziona do domu dziecka sióstr urszulanek w Otorowie ${ }^{21}$. Ojciec był niewidomy. Przeżył, ale trudno mu było odnaleźć się w nowej rzeczywistości. Ożenił się ponownie z dawną koleżanką matki. Barbarze urodziła się jeszcze jedna siostra. W domu dziecka wróciło widmo przemocy seksualnej:

I tam [w domu dziecka - J.O.] nam siostry zrobiły miejsce w piwnicach, bo będzie wracało wojsko. Z Berlina. I był jakiś taki okres, kiedy wolno nam było wychodzić dopiero wieczorem, na jakiś posiłek. To trwało może tydzień, może dziesięć dni. Nie wiem. Nie widziałam tego wojska. Nam kazano się chować, szczególnie dziewczynom. One [siostry - J.O.] zdawały sobie sprawę, że będą znowu gwałcić.

I choć nie doszło do żadnego aktu przemocy, to Barbara nie zdecydowała się opowiedzieć o swoich poprzednich doświadczeniach siostrom. Bardzo szybko chciała się usamodzielnić. Najpierw skończyła szkołę pielęgniarską i w 1952 roku rozpoczęła pracę na oddziale neurochirurgii przy Klinice Laryngologicznej w Poznaniu. Po trzech latach zdała na studia medyczne i wróciła na oddział na początku 1965 roku już jako anestezjolożka. W latach 70. zaczęła uczyć (Studium Medyczne nr $1 \mathrm{w}$ Poznaniu) ${ }^{22}$, skończyła dodatkowo studia pedagogiczne i do 1983 roku opiekowała się bratem, który był osobą z niepełnosprawnością

${ }^{21}$ W dwóch zeszytach, w których zapisano dane osobowe dzieci przebywających po wojnie w domu dziecka w Otorowie, nie było nazwiska Barbary i jej brata. Trudno powiedzieć dlaczego, być może to niepełna dokumentacja. Zachowane fotografie $\mathrm{z}$ tamtego okresu nie zostały podpisane - nie można nikogo zidentyfikować (informacje na podstawie pochodzącej z mojego archiwum korespondencji mailowej z siostrą B. Marciniak z listopada 2019 r.).

${ }^{22}$ Zob. W. Kukla: Z dziejów poznańskiej neurochirurgii w latach 1952-1997. Poznań 1998, s. $15,37,61$. 
fizyczną. Jej kariera zawodowa wygląda imponująco. O przemocy seksualnej w trakcie wojny usłyszała jeszcze tylko raz - od swojej koleżanki w trakcie bardzo niezobowiązującej rozmowy:

To, co wiem, to o tej matce mojej koleżanki: ci państwo mieszkali w Chojnicach. Mąż był wpisany na listę folksdojczów. Moja koleżanka i jej mama już nie żyją. Ona [koleżanka - J.O.] była młodsza ode mnie. Urodziła się w 1939 roku. Jej to nie groziło. Wspomniała mi kiedyś: „Moja mama została zgwałcona”. Tylko tyle. Nie była to okazja, żebym ja jej mogła powiedzieć: „Ja też”.

Barbara bardzo otwarcie opowiedziała mi o swoim życiu seksualnym. Gwałt, który często nazywała „tym”, uniemożliwił jej jakiekolwiek kontakty z mężczyznami:

Nigdy nie miałam mężczyzny. Poza „tym”. Każda próba zbliżenia kończyła się ucieczką. Zawsze było wielkie zdziwienie: „Co się z Tobą dzieje?” Ale nie potrafiłam wtedy powiedzieć... Starałam się to wyprzeć, zepchnąć do niepamięci, żeby mi to nie przeszkadzało w życiu. Zbliżenie z mężczyzną to był strach, panika wręcz. Ja dosłownie uciekałam. No i stąd nie było żadnej możliwości wyjścia za mąż, czy coś takiego.

Kiedy Barbara przeczytała artykuł Kobieca gehenna w tygodniku „Polityka”, popłakała się: „Długo się zastanawiałam, czy napisać. Chyba nie napisałam zaraz po...”. Rzeczywiście, minęły dwa tygodnie, zanim dostałam pierwszego maila. Na sam koniec naszego spotkania raz jeszcze zapytałam o przerwanie milczenia i o samo świadectwo: „Myślę, że teraz jest już za późno na zmianę myślenia o »tym«. Osoby, których to dotyczyło, ich dzieci już schodzą ze sceny. [...] Ja nie czekałam [na nikogo - J.O.]. Nie myślałam o tym. Nie przypominało mi się to w snach. [...] Nie czuję teraz ulgi, że to powiedziałam. Może to przyjdzie po paru dniach. Nie wiem, nie umiem powiedzieć”.

\section{Alaine: „Proszę, córeczko, powiedz, że to nieprawda!”}

Csákvár - tak nazywała się wieś, w której ukrywała się Alaine Polcz wraz ze swoim mężem i teściową. Trafiła tam po ucieczce z Rumunii na Węgry, ponieważ matka jej męża była klucznicą na dworze hrabiów Esterházych w tej miejscowości. Spędziła tam kilka miesięcy, aż do wyjazdu do Budapesztu, gdzie udała się w poszukiwaniu bliskich, którzy być może przetrwali. Ten obszar był wyjątkowo niebezpieczny ze względu na zmieniającą się wtedy linię frontu.

Po wojnie Polcz pracowała jako psycholożka. Założyła pierwszą węgierską organizację zajmującą się opieką hospicyjną. Była znaną prozaiczką, autorką 
kilkudziesięciu książek. W 1991 roku ukazała się jej autobiografia Asszony a fronton („Kobieta na linii frontu” ${ }^{23}$, z której pochodzą wszystkie przytoczone dalej fragmenty dotyczące okresu przed majem 1945 roku$^{24}$.

Polcz nazywała swoją teściową „mamcią” i to z nią była związana przez cały okres gehenny wyzwolenia przez Armię Czerwoną. Na początku, jeszcze z mężem Jánosem, cała rodzina próbowała ukrywać się na miejscowej plebanii. Pewnej nocy jednak radzieccy żołnierze wtargnęli do budynku i wyprowadzili wszystkich mężczyzn. Kobiety schroniły się w piwnicy. Wczesnym rankiem Alaine, która miała wtedy dwadzieścia trzy lata, udała się do lokalnej komendantury, aby dowiedzieć się, co z aresztowanymi:

Zebrało się tam już sporo ludzi, którzy czekali w kolejce. Siedziała między nimi zrozpaczona dziewczynka. Na zakrwawionej głowie brakowało jej kępki włosów.

- Przejechali się po niej Rosjanie - powiedziała jej matka.

Nie rozumiałam.

- Rowerem?

- Z księżyca pani spadła? - wybuchła kobieta. Nie wie pani, co oni robią $\mathrm{z}$ kobietami?

Zaczęłam przysłuchiwać się, co mówią ludzie. Jednej kobiecie pękł kręgosłup, inna straciła przytomność, jeszcze innej nie mogą zatamować krwotoku. Zastrzelono też mężczyznę, który próbował bronić żony. Nagle odsłoniła się przede mną cała otaczająca nas groza ${ }^{25}$.

W mgnieniu oka postrzeganie otaczającej rzeczywistości przez Alaine zmieniło się nie do poznania. Dotychczasowe kontakty z Armią Czerwoną były raczej przyzwoite. Kobieta podejrzewała, że być może jej mąż wiedział coś na temat fali gwałtów, ale nie chciał o tym mówić: „Nie mieliśmy pojęcia o bożym świecie"26.

Po jakimś czasie grupa żołnierzy znów wtargnęła na plebanię. Jeden z nich wybrał Alaine i pokazał jej zdjęcie męża. Zagroził, że go zabije, jeśli kobieta $\mathrm{z}$ nim nie pójdzie. Od tego momentu Alaine była gwałcona wielokrotnie. Bardzo

${ }^{23}$ Książka Polcz została przetłumaczona na: francuski (1995), angielski (1998), niemiecki (2012) i hiszpański (2017). Zsófia Lóránd napisała artykuł o zjawisku współczesnego przemilczania gwałtów wojennych i szerzej: przemocy seksualnej na Węgrzech w okresie drugiej wojny światowej. Por. Z. Lóránd: Exhibiting Rape, Silencing Women. Alaine Polcz in the House of Terror in Budapest. "East Central Europe" 2015, no 42, s. 321-342.

${ }^{24}$ Autobiografia Polcz nie ukazała się po polsku. Dysponujemy tylko fragmentami opublikowanymi w „Literaturze na Świecie” i w kwartalniku „Karta”. Cytaty w tym tekście pochodzą z „Karty”: A. Polcz: Kobieta na froncie. Przeł. M. Roguska. „Literatura na Świecie” 2014, nr 3-4 (512-513), s. 339-374; A. Polcz: Kobieta na linii frontu. Przeł. K. Wilamowska. Wybór G. Danyi. „Karta” 2018, nr 95, s. 101-115.

${ }^{25}$ A. Polcz: Kobieta na linii frontu..., s. 103.

26 Tamże. 
emocjonalnie opisuje proces wyparcia tych przeżyć, reakcje otoczenia oraz to, jak szybko stosunek seksualny stał się „walutą” na terenach wyzwalanych:

Chłopak powiedział „twoj muż i gestem pokazał, że go zastrzelą. Potem z uśmiechem zaprosił mnie do pokoju. Poszłam z nim, wiedziałam, czego chce. Położył fotografię na szafeczce nocnej i pchnął mnie na łóżko. Bałam się, że nie odda mi zdjęcia. Kiedy skończył, wziął je do ręki i znów mi pokazał (dalej bałam się, że mi go nie odda). [...] Jakoś się pozbierałam i wróciłam. Mamcie mi się przyglądała. Myślę, że doskonale wiedziała, co się stało, ale nie rozmawiałyśmy o tym ${ }^{27}$.

Już po pierwszym gwałcie Alaine milczała. Nie rozmawiała o tym z teściową i z innymi kobietami z plebanii. Wszystkie chowały swoje rzeczy i kosztowności, żeby uchronić się przed grabieżą. Nie zdecydowały się na spanie w jednym pomieszczeniu dla bezpieczeństwa. Prawdopodobnie czuły się bezsilne. Gwałt na Alaine powtórzył się kilka dni później. Teściowa Polcz próbowała interweniować:

Nagle przyszło trzech Rosjan i powiedzieli po rumuńsku, żebym z nimi poszła. Dobrze wiedziałam, czego chcą. Nie wiem skąd, ale wiedziałam. Powiedziałam Mamci, że zabierają mnie do szpitala do opatrywania rannych. Mamcia spojrzała na mnie, zaczęła błagać: „Nie idź z nimi dziecko, nie idź, bo zrobią ci krzywdę". Powiedziałam im, że matka (nie chciałam mówić, że to teściowa) nie chce mnie puścić. Wtedy pokazali na podkute żelazem drzwiczki pieca, mówiąc po rumuńsku, że jeśli nie pójdę, rozbiją o nie głowę Mamci [...]. Po węgiersku powiedziałam Mamci, że jest dużo rannych i muszę iść. [...] Objęłam i ucałowałam Mamcię: „Będę tylko tyle, ile trzeba”. Powiedziałam, żeby pomyślała o rannych. Mamcia spojrzała na mnie i zaczęła płakać ${ }^{28}$.

Kobietę zaszantażowano i wyprowadzono bez użycia siły, grożąc, że jeśli nie ulegnie, to ktoś skrzywdzi jej bliskich. Ten fragment o „opatrywaniu rannych” stanie się w finale opowieści Polcz czymś w rodzaju zasłony dymnej maskującej przemoc seksualną. Historia córki, która była wielokrotnie gwałcona, stanie się czymś niewyobrażalnym. Opatrująca rannych żołnierzy sanitariuszka to jedyna figura, która pasowała do powojennego dyskursu o wyzwolicielach:

Z całej siły kopałam ich i biłam rękami, ale po chwili już leżałam na ziemi. Nikt nie wydał z siebie najmniejszego dźwięku, ani oni, ani ja, szamotaliśmy się w ciszy. Zaciągnęli mnie do kuchni i rzucili na podłogę [...]. Straciłam przytomność. [...] Ocknęłam się w wewnętrznej sypialni dziekana. [...] Wraz ze świadomością nie wróciło mi czucie, jakbym odrętwiała lub skostniała. Musiałam zmarznąć, leżąc półnago w zabitym, nieogrzewanym pokoju. Nie wiem,

\footnotetext{
27 Tamże, s. 103-104.

28 Tamże, s. 105.
} 
ilu było później Rosjan, ilu wcześniej. Poszli o świcie. Z trudem podniosłam się, ledwie mogłam się ruszać. Bolała mnie głowa, całe ciało. Mocno krwawiłam. Nie czułam się zgwałcona, ale fizycznie skrzywdzona. To nie miało nic wspólnego z seksem, z dotykiem. To z niczym nie miało nic wspólnego. To była zwykła przemoc ${ }^{29}$.

Każda kolejna opowieść w relacji Alaine Polcz jest coraz bardziej brutalna. Refleksja nad naturą przemocy seksualnej narodziła się prawdopodobnie o wiele później, kiedy powstawała książka (przełom lat 80. i 90. XX wieku). Ofiara mówi wprost o ekstremalnej formie wojennej brutalności, która wielokrotnie uprzedmiotowiła jej ciało. Niestety dla wielu postronnych świadków, często ofiar, te doświadczenia nie były tożsame z cierpieniem. Wiązano je raczej z „dobrowolną” decyzją, seksualną przyjemnością bądź z pracą seksualną za obopólną zgodą:

Pewnej nocy naszedł nas cały oddział, było ciemno i zimno, strzelali. W pamięci utkwiła mi pewna scena: leżałam na ziemi, a dookoła mnie kucało ośmiu, dziesięciu rosyjskich żołnierzy, którzy po kolei się na mnie kładli. Pozostali odliczali im czas. Patrzyli na zegarek, palili zapałki, jeden miał nawet zapalniczkę. Pospieszali się nawzajem. [...] Myślałam, że umrę. Ale człowiek nie umiera tak łatwo. Chyba że pęknie mu kręgosłup, ale nawet wtedy nie od razu. [...] Nad ranem zrozumiałam, dlaczego pęka kręgosłup. Otóż zadzierają kobiecie nogi i przyginają je, aż do ramion, a potem gwałcą ją z pozycji klęcznej. Jeśli ktoś zrobi to zbyt mocno, łamie kobiecie kręgosłup. Nie zabija jej umyślnie, tylko z nadmiernej siły. Szarpie do przodu i tyłu zgięty w kabłąk kręgosłup kobiety i nawet nie zauważa, kiedy ten pęka. [...] Uszkodzili mi kręgosłup, ale go nie złamali. Moje plecy zmieniły się w krwawą ranę, do której przykleiły się sukienka i halka, ale wówczas tego nie zauważyłam. Tak bardzo bolało mnie całe ciało, że nawet nie zwróciłam na to uwagi ${ }^{30}$.

Ciało kobiety stało się dosłownie trofeum, które można było „zdobyć na czas”. Ten fragment relacji Polcz jest wstrząsający również dlatego, że mówi o rzeczywistym naznaczeniu gwałconej kobiety i wskazuje na niebezpieczeństwo utraty życia podczas gwałtu. Krwawiąca rana, która powinna budzić współczucie, paradoksalnie, z czasem wywoływała odrazę innych. Stała się czymś obrzydliwym:

Kiedy w piwnicy rozpleniły się wszy, rozebrałam się, żeby wybrać je z bielizny. Jakaś kobieta stojąca za mną krzyknęła. Zdejmując halkę, rozjątrzyłam sobie ranę na plecach. Kobieta spytała, nie kryjąc odrazy, czy jestem świadoma tego, że mam żywą ranę na plecach. Zbiegli się ludzie, zaczęli przyglądać się moim plecom (zraniłam je wtedy, gdy żołnierze gwałcili mnie, doginając mi nogi do ramion) [...].

\footnotetext{
29 Tamże, s. 106.

30 Tamże.
} 
Raz zszedł do piwnicy rosyjski żołnierz, spałam. On obudził mnie, nachylił się i zaczął mną potrząsać. Ta sama kobieta, która zwróciła mi uwagę na moją ranę, powiedziała, że na mojej twarzy odmalowało się przerażenie, jakie widzi się czasem u koni. [...] Potem zaczęły się pertraktacje, błagania po rumuńsku. Po węgiersku zaś zaklinałam pozostałych: „Niedaleko stąd jest komendantura, niech ktoś tam pójdzie i poprosi o pomoc! [...]”. Ale nikt się nie ruszył. Osiemdziesiąt osób słuchało bezczynnie moich błagań. Pokazałam, że przytrzymam lufę karabinu, żeby żołnierz nie mógł strzelić. Bali się, milczeli i pozwolili, żeby mnie zgwałcono na ich oczach i na oczach ich dzieci ${ }^{31}$.

Wspomniana przez Alaine kobieta to postać symboliczna. Z jednej strony oceniające oko tłumu, które ogląda poranione ciało ofiary, z drugiej - bezimienny świadek zdarzenia, w którego pamięci zapisywała się przemoc seksualna. Powojenne relacje - często w trzeciej osobie liczby pojedynczej - przypominają opowieści niemych widzów przemocy. Najbardziej symptomatyczne są jednak ich reakcje: awersja, odrzucenie, absmak, które były związane nie tylko ze stanem zdrowia kobiety, ale przede wszystkim z samym gwałtem, po którym pozostał widoczny ślad.

Brak odpowiedzi na agresję radzieckiego żołnierza mógł tłumaczyć tylko strach. Zresztą w kolejnym zdaniu autorka relacji odwraca perspektywę - piszę o pewnym współuzależnieniu w sytuacji zagrożenia życia, kiedy bardzo niewielu jest w stanie stanąć w obronie skrzywdzonego. Bohaterstwo - wbrew narodowej mitologii - dotyczyło nielicznych. Jednocześnie ciągły lęk wywoływał apatię ${ }^{32}$ : „Jak potrafią sobie to wybaczyć? A jak ja potrafię sobie wybaczyć to, że komuś nie pomagam, bo się boję - i jak często nie pomagam..."33.

Niejednokrotnie reakcje postronnych były bardziej brutalne. Z czasem ofiary gwałtów czuły się więc tak, jakby były winne bardziej niż sami sprawcy. Skoro relacje seksualne stały się cenną walutą, a kobiety „dobrowolnie” ${ }^{4}$ oddawały się

31 Tamże, s. 110-111.

${ }^{32}$ Marcin Zaremba pisze m.in. o zjawisku powojennej bierności i apatii: „Długotrwałe obcowanie ze strachem może prowadzić również do konformizmu, społecznej apatii i bierności. W czerwcu 1945 r. powojenną, psychiczną kondycję mieszkańców Wielkopolski podziemie opisywało w ten sposób: »Stan psychiczny ludności miejscowej to wciąż jeszcze niewygasły lęk oraz bierność i typowy rodzaj barwy ochronnej, legalizm. Nie nastąpiło jeszcze odrodzenie wewnętrzne, nie skrzepło dobre samopoczucie. Polacy nie czują się pełnowartościowi, są stłumieni i apatyczni, a kłopoczą się wyłącznie trudnościami materialnymi codziennego dnia. Z marazmu niełatwo ich obudzić«" (M. Zaremba: Wielka Trwoga..., s. 108).

33 A. Polcz: Kobieta na linii frontu..., s. 111.

34 Kwestia dobrowolności pojawia się w relacjach większości ofiar przemocy seksualnej, także współcześnie. W okresie drugiej wojny światowej i po wojnie dominował „mit dobrowolnego meldunku”, zgodnie z którym seksualne pracownice przymusowe „dobrowolnie” meldowały się w domach publicznych dla Niemców albo w obozach - dla więźniów. Nikt nie brał pod uwagę sytuacji okupacyjnej, samego konfliktu zbrojnego, sytuacji zagrożenia zdrowia i życia. Por. Ch. Paul: Zwangsprostitution. Staatlich Errichtete Bordelle im Nationalsozialismus. Berlin 1994; 
zdobywcom, żeby przetrwać, to ofiary były same sobie winne - nikt nie pamiętał o sytuacji zagrożenia życia, zdrowia, o powszechnym głodzie i próbach przetrwania za wszelką cenę. Często w obronie swoich rodzin:

Przez okno zauważył mnie dowódca komendantury. Nie wiem jak, ale mnie odnalazł i kazał do siebie sprowadzić. Zabrali mnie jak na oficjalne przesłuchanie. Piwnica znajdowała się tuż obok komendantury. Przyjął mnie serdecznie, dostałam dobrą kolację. Czekałam, co będzie dalej. Powiedział, że jeżeli zostanę na noc, da mi pół świniaka. Dobry Boże - pół świni, w tamtych czasach! [...] Wczesnym rankiem poprosiłam, żeby pozwolił mi odejść. Na korytarzu spotkałam kucharkę, która wcześniej gotowała w szpitalu. Zmierzyła mnie wzrokiem, szpitalną „maskotkę”. Oddałam się, chociaż mnie nie bili - widziałam w jej spojrzeniu, co o mnie myśli. Że jestem kurwą. Właściwie byłam nią w ścisłym tego słowa znaczeniu. Kurwa to ta, która oddaje się za pieniądze lub inne korzyści. Kurwa to ta, która świadomie wykorzystuje swoje ciało, żeby coś zdobyć. Mleko lub materac. Wtedy nie przyszło mi to do głowy. Nie myślałam o tym. O niczym nie myślałam. Czułam tylko jakąś gorycz. Nieznośność nie tyle ostatniej nocy, ile tego wszystkiego. Szary poranek... Czym był? Szczytem ludzkiego upokorzenia - nie dostałam połówki świni. Odetchnęłam z ulgą ${ }^{35}$.

„Nieznośność” i „szczyt ludzkiego upokorzenia” - trudno o bardziej dosadne określenia. Coś, czego nie da się znieść, ale nie może się skończyć. Opis Polcz jest wręcz makabryczny, może dlatego, że tak bardzo szczegółowy. Kobieta planuje, co powinna zrobić, żeby nie zostać wykreślona ze społeczności. W tej sytuacji tylko przemoc fizyczna warunkowała jakiekolwiek zrozumienie przymusowego seksu. Trzeba też było walczyć. Strategie przetrwania były bardzo różne: od brudzenia twarzy i udawania starszych kobiet, po ataki epilepsji i podejrzenie chorób psychicznych. Nigdy nie można było być pewną: „Narzuciłam na głowę czarną chustę, rozsmarowałam na twarzy błoto i popiół [...]. Pewna dziewczynka o imieniu Marianne uniknęła naszego losu, bo zaczęła toczyć pianę z ust i wywróciła oczy białkami do góry. Zostawili ją w spokoju, ale zabrali jej babkę. [...]”36.

Jednocześnie pojęcie dobrowolności, które pojawia się w przywołanym fragmencie, stało się niezwykle istotnym wyznacznikiem powojennego naznaczania kobiet - ofiar przemocy seksualnej. W oczach kucharki Alaine była maskotką, która wyłącznie czerpała zyski - korzystała z sytuacji wojennej, dorabiała sobie. Dla Polcz te kilka miesięcy to szczyt upodlenia, z którym trudno było się skonfrontować - i o którym na dobrą sprawę nie sposób opowiedzieć. Obie wizje są do dnia dzisiejszego praktycznie nie do pogodzenia.

R. Sommer: Das KZ-Bordell. Sexuelle Zwangsarbeit in nationalsozialistischen Konzentrationslagern. Paderborn 2010.

${ }^{35}$ A. Polcz: Kobieta na linii frontu..., s. 112.

${ }^{36}$ Tamże, s. 107, 111. 
Powrót do domu w przypadku Alaine można z całą pewnością uznać za moment „weryfikacji” ofiary/ocalonej/przeżywca. Czasem to rodzina okazywała się najbardziej brutalnym powojennym sędzią:

Mama oczywiście płakała, była szczęśliwa, tuliła mnie do siebie. Patrzyłam na nią i cieszyłam się z jej szczęścia. Cieszyłam się, że żyją, ale nie jakoś bardzo.

[...] Na kolację był ozór w sosie pomidorowym. Jadłam w milczeniu, nie dowierzając własnym oczom.

- Mówią, że Rosjanie gwałcili kobiety. U was też? - zapytała mama.

- Tak, u nas też.

- Ale ciebie nie?

- Ależ tak, wszystkie - powiedziałam.

Mama patrzyła na mnie przez chwilę i zapytała ze zdziwieniem:

- Jak mogłaś na to pozwolić?

- Bo mnie bili - odpowiedziałam i jadłam dalej.

Kwestia ta nie wydawała mi się ani ważna, ani ciekawa. Na to ktoś zapytał lekko, wręcz żartobliwie:

- A dużo ich było?

- Trudno zliczyć - powiedziałam, wciąż nie przerywając jedzenia ${ }^{37}$.

„Jak mogłaś na to pozwolić?" Alaine jest przepytywana w trakcie posiłku, który w perspektywie ostatnich kilku miesięcy głodu i poniewierki wydaje się czymś niezwykłym - wszystko inne nie ma znaczenia. Reakcja matki nie wywołuje zdziwienia. Żartobliwe pytania innych bliskich szacujących liczbę gwałcicieli też nie robią na kobiecie żadnego wrażenia. Jedzenie jest ważniejsze niż drwiny. Dopiero po kolacji matka wróci do tematu przemocy seksualnej, już sam na sam z córką:

- Córeczko, nie rób sobie takich brzydkich żartów, bo jeszcze uwierzą! Spojrzałam na nią:

- Mamo, to wszystko prawda.

Rozpłakała się i mnie objęła. Wtedy powiedziałam:

- Wszystkie nas zabierali i wszystkie gwałcili. Mówiliście, że u was też.

- Tak, ale tylko kurwy. A ty nie jesteś kurwą - powiedziała mama ${ }^{38}$.

„Brzydkie żarty” to synonim masowych gwałtów wojennych. Owe słowa padają z ust matki ofiary, której ta zdecydowała się opowiedzieć o swoich doświadczeniach. Choć prawdziwe i powszechne - były one nie do zaakceptowania, bo w powszechnym mniemaniu przecież gwałcono tylko te, które należały do tzw. społecznego

\footnotetext{
37 Tamże, s. 114-115.

38 Tamże, s. 115.
} 
marginesu ${ }^{39}$. Przemoc seksualna dotyczyła wyłącznie pracownic seksualnych „zwykłe obywatelki” po prostu nie mogły być na nią narażone:

Rzuciła mi się na szyję i zaczęła błagać:

- Proszę, córeczko, powiedz, że to nieprawda!

- Dobrze - zgodziłam się - to nieprawda, zabrali mnie do szpitala, żebym opatrywała rannych ${ }^{40}$.

\section{Zofia i Anna: „Gwałtu nie używałem, oddała się sama”}

Sprawa przeciwko Zygmuntowi Frostowi rozpoczęła się od pisma z 1 lipca 1945 roku, w którym zdecydowano o zastosowaniu środka zapobiegawczego wobec podejrzanego. Na druku nie podano artykułu, na podstawie którego zatrzymano Frosta $^{41}$. Dwa dni później kierownik Powiatowego Urzędu Bezpieczeństwa Publicznego Tadeusz Liguziński ${ }^{42}$ zgłosił kierownikowi Wojewódzkiego UBP popełnienie przestępstwa przez mężczyznę, który sprawował urząd komendanta Powiatowego Urzędu Bezpieczeństwa w Sopocie: „Dnia 30.06.1945 roku komendant Zygmunt Frost upił się i w stanie nietrzeźwym pobił jedną aresztowaną, po przeprowadzeniu śledztwa okazało się, że Frost podczas wykonywania swoich czynności służbowych wyprowadzał z celi aresztowane kobiety i je gwałcił"43. Liguziński domagał się wydelegowania pracownika śledczego, który miał przeprowadzić dochodzenie. Śledztwo wszczęto 9 lipca ${ }^{44}$ po serii przesłuchań, w których brały udział także ofiary. Zygmunt Frost opuścił areszt 24 września ${ }^{45}$ - przebywał w nim prawie trzy miesiące; został uniewinniony.

Pobitą przez Frosta kobietą była Zofia Ernst Lamparska. Od 6 czerwca tego roku przebywała $\mathrm{w}$ areszcie UBP $\mathrm{w}$ Sopocie. W chwili zatrzymania miała czterdzieści trzy lata. W części personalnej Protokołu przesłuchania świadka ${ }^{46}$.

39 O dekryminalizacji i uznaniu pracy seksualnej współcześnie w Europie pisze m.in. Agata Dziuban. Por. Taż: Dekryminalizacja, praca, intersekcjonalność, uznanie: ramy ruchu pracownic i pracowników seksualnych w Europie. „Przegląd Socjologii Jakościowej” 2018, nr 14 (1), s. $12-44$.

40 A. Polcz: Kobieta na linii frontu..., s. 115.

${ }^{41}$ Archiwum Instytutu Pamięci Narodowej (dalej: AIPN), BU 813/57, k. 5.

42 T. Liguziński był kierownikiem Powiatowego UBP/Delegatura w Gdańsku między 15 kwietnia a 20 października 1945 r.: „W październiku 1945 r. aresztowany jako współpracownik siatki wywiadu WiN na Pomorzu; faktycznie odsunięty od pracy w końcu sierpnia 1945 r., 23 III 1946 r. formalnie zwolniony ze stanowiska” (Aparat bezpieczeństwa w Polsce. Kadra kierownicza. T. 1: 1944-1956. Red. nauk. K. Szwagrzyk. Warszawa 2005, s. 158).

43 AIPN, BU 813/57, k. 3.

44 Por. tamże, k. 2.

45 Por. tamże, k. 44.

46 Tamże, k. 12. 
Zofia deklarowała:

Zawód: właścicielka sklepu

Wykształcenie: szkoła handlowa

Narodowość: obywatelstwo gdańskie [w kolejnym zeznaniu: Polka; w relacji

Frosta: Niemka; w akcie oskarżenia: folksdojczka - J.O.].

Stan cywilny: wdowa

Mieszkała w Sopocie przy ulicy Rokossowskiego [dziś Bohaterów Monte Cassino - J.O. $]^{47}$.

Pierwsze pytanie oficera śledczego brzmiało: „Co możecie powiedzieć o Froście?”. Zofia opowiedziała o pierwszym gwałcie:

Jakieś osiem dni temu przyszedł do celi komendant więzienia i wywołał moje nazwisko. Ja się zgłosiłam do niego, który mnie poprowadził za rękę w koniec korytarza gdzie stała ławka było bardzo ciemno. Tam usłyszałam jego głos „zdejmuj majtki!”. Ja nie chciałam ze strachu zdjęłam i kładłam się na ławce na której mnie zgwałcił. Ja się nie broniłam ani nie krzyczałam bo się bardzo bałam. To trwało może dziesięć minut gdzie po tym zaprowadził mnie z powrotem do celi. Działo się to około godziny $24.00^{48}$.

Frost zgwałcił jedną z więźniarek, ponieważ czuł się bezkarnie w areszcie, w którym był przecież komendantem. Sytuacja powtórzyła się kilka dni później. Tym razem Zofia została zabrana do mieszkania komendanta:

Tam mnie zostawił każąc się myć a potym kłaść do łóżka, sam wyszedł, gdzie to nie wiem. Po pół godzinie przyszedł ze śpiewem [...], potym się rozebrał i położył do łóżka koło mnie. W łóżku przeleżałam około 2 godzin w czasie którego mnie zgwałcił. Na zapytanie, że to się może wydać? Odpowiedział: „Ja bym tych kurwów zabił”. [...] Gdy leżałam z nim w łóżku powiedziałam mu że tą blondynkę, która u niego sprząta też chyba używa? Na co mi odpowiedział ja każdą mogę wziąć, którą tylko chcę i mnie każda się musi oddać $[\ldots]^{49}$.

Wspomniana blondynka miała na imię Anna. Złożyła zeznania kilka dni później. Lamparska została trzykrotnie uderzona w twarz, ponieważ poprosiła Frosta o kawałek chleba dla Anny i dla siebie. Komendant bił kobietę i krzyczał: „Co ty kurwo ja dawałem chleb?”, „A ty nie jesteś Frydmanowa kurwa, nie chodzisz do Frydmana”. Ten incydent zakończył się interwencją jednego ze strażników. Po jakimś czasie Zofię zapytano, czy Frost ją uderzył - zaprzeczyła.

\footnotetext{
47 Tamże.

48 Tamże, k. 13.

49 Tamże.
} 
Na pytanie śledczego, dlaczego kłamała, kobieta powiedziała: „Dlatego, że się go bardzo bałam ponieważ po nim można się wszystkiego spodziewać i bałam się zemsty" 50 .

Zygmunta Frosta przesłuchano 6 lipca. Mężczyzna miał czterdzieści pięć lat. Urodził się w Pińsku, mieszkał w Sopocie. Był żonaty i miał trójkę dzieci. Polak, katolik, rolnik, ukończył sześć klas szkoły powszechnej. Posiadał dwa hektary ziemi - dom i gospodarstwo. Służył w wojsku w latach 1919-1921 i podczas kampanii wrześniowej. $\mathrm{W}$ trakcie okupacji pracował między innymi jako grabarz. W zeznaniach Frosta ani razu nie padło imię i nazwisko Zofii Lamparskiej. Pierwsze pytanie śledczego brzmiało: „W jakim celu wywołaliście nazwisko pewnej kobiety i gdzie żeście ją zaprowadzili?"'51. Frost odpowiedział, że zaprowadził ją na korytarz, żeby zapalić z nią papierosa i odbyć stosunek: „[...] ona mi się spodobała i postanowiłem z nią mieć stosunek”52. Ani słowa o przymusie i władzy komendanta aresztu.

Gwałt w mieszkaniu został opisany przez Frosta jako wynik umizgów Zofii, która „narzucała” się komendantowi. Dodatkowo namawiała go do „różnych” praktyk, które były mu nieznane: „[...] oświadczam, że ona się narzucała, gdyż w swoim życiu jeszcze tego [seks oralny - J.O.] nie przeżywałem, mając nawet żonę i troje dzieci, nie wiedziałem o czymś podobnym" ${ }^{33}$. Przemoc seksualna została przedstawiona przez sprawcę jako ni mniej, ni więcej atak samej kobiety, spragnionej „nienaturalnych” aktów seksualnych, co miało podważać zarzut gwałtu. Frost zapytany o strach Zofii odpowiedział krótko: „Nie była w strachu, gdyż ja powiedziałem, żeby była spokojna" ${ }^{\text {. }}$.

Kolejne pytania dotyczyły innych aresztantek, które pracowały dla Frosta. Mężczyzna wspominał, że po prostu traktował je jak służące: „Chcąc zdobyć każdą aresztantkę to przyznaję się, że mogłem, ale na to sobie nie pozwalałem" ${ }^{\prime 5}$. Pobicie i wyzwiska rozmyły się w pamięci komendanta, ponieważ był pijany. $\mathrm{Na}$ końcu swojego zeznania oświadczył, że: „[...] nie wykonałem gwałtu, tylko ją polubiałem i dlatego z nią miałem stosunek" ${ }^{\prime 56}$.

W tym samym dniu wezwano raz jeszcze Zofię Lamparską. Kobieta ponownie opowiedziała o pierwszym gwałcie - ze wszystkimi szczegółami: „[...] powiedział do mnie tonem rozkazującym zdejm majtki”57; „[...] wszedł do łóżka. Będąc w łóżku wyzywał do mnie kurwa Twoja mać, ja mogę każdą kurwę mieć,

\footnotetext{
50 Tamże, k. 14-15.

51 Tamże, k. 7-8.

52 Tamże, k. 8.

53 Tamże.

54 Tamże.

55 Tamże, k. 9.

56 Tamże.

57 Tamże, k. 10.
} 
jak która mi nie da to ją zabiję"58. Po przymusowym stosunku seksualnym Frost opowiedział Zofii o swojej żonie i córce, które są na Syberii, oraz o synu w niewoli niemieckiej. Być może chciał wzbudzić litość.

Przesłuchanie Zofii zostało powtórzone ze względu na podejrzenie „nienormalnego stosunku” w mieszkaniu Frosta, do czego mężczyzna rzekomo został namówiony przez kobietę. Nikt nie zwracał uwagi na to, że ponowne zeznania mogą być dla ofiary traumatyczne - w końcu tym razem występowała jako podejrzana. Zofia Lamparska była jedną z aresztantek. W areszcie przebywała tylko kilka dni. Z akt sprawy Frosta nie wynika, za co została zatrzymana:

- Czy tej nocy miał on z panią nienormalny stosunek?

- Twierdzę że nie.

- Czy pani się jemu narzucała?

- Nie narzucałam się, tylko kiedy miałam być zwolniona uścisnęłam mu rękę w obecności wszystkich ${ }^{59}$.

Następnie Zofia raz jeszcze wspomniała o Annie Ewald, która również była narażona na przemoc ze strony Frosta. Pod sam koniec zeznania znów pojawiła się informacja o strachu i braku jakiejkolwiek możliwości buntu: „[...] ja oporu nie mogłam stawić, gdyż byłam bezwładna, proszę przesłuchać resztę świadków"60.

W tej sprawie przesłuchano jeszcze dwie kobiety: Annę Ewald i Gertrud Weinert. Obie odpowiadały na pytania oficera śledczego Leona Zakrajczyka 9 lipca. Kobiety nie znały języka polskiego, odpowiadały po niemiecku i ze względu na brak tłumacza polską wersję zeznań sporządził prowadzący przesłuchanie. Trudno powiedzieć, jak dokładne było to tłumaczenie, skoro relacje obu kobiet to tylko kilkanaście linijek tekstu ${ }^{61}$.

Anna Ewald miała trzydzieści lat, pochodziła ze Śląska i była mężatką. Ukończyła osiem klas szkoły powszechnej. W rubryce „zawód” wpisała: przy mężu. Mieszkała w Sopocie przy ul. Chopina. Od samego początku przesłuchania nie traktowano jej jak ofiary gwałtu:

- Proszę mi opowiedzieć jak doszło do tego że oddała się Pani Frostowi Zygmuntowi?

- Frost Zygmunt [...] wykorzystywał fakt że ja byłam aresztantką i zabierał mnie do siebie do pokoju do pracy, w tym czasie zmuszał mnie do uległości. Na moje zapytanie, czy to również należy do moich obowiązków oświadczył, że o ile nie zgodzę się na stosunek z nim zamelduje kierownikowi Urzędu o tym, że zachowuję się niewłaściwie w więzieniu, a ten mnie za to surowo ukarze.

\footnotetext{
58 Tamże, k. 11.

59 Tamże.

60 Tamże.

${ }^{61}$ Por. tamże, k. 16-21.
} 
Obawiając się że Frost faktycznie tak postąpi oddałam mu się. Frost mnie uprzedził żeby o tym nikomu nie mówićc ${ }^{6}$.

Anna była wykorzystywana przez Frosta jako służąca i została przez niego trzykrotnie zgwałcona. Mężczyzna czuł się bezkarny, wiedząc, że życie kobiety, w szczególności Niemki, zależy tylko od niego. W tamtym bowiem czasie w stosunku do ludności pochodzenia niemieckiego, która nie zdążyła uciec, zachowywano się bardzo brutalnie, bez zahamowań. Traktowano to jako zemstę za czasy wojny. Przemoc seksualna była na porządku dziennym - także w więzieniach, aresztach i polskich obozach MBP dla Niemców ${ }^{63}$.

Drugą świadkinią była czterdziestodwuletnia Gertrud Weinert - mieszkanka Sopotu (ul. Parkowa), z zawodu biuralistka. Ukończyła siedem klas szkoły powszechnej, była panną. Zeznała, że Frost zaproponował jej wspólną kąpiel: „[...] w czasie gdy prałam u niego w pokoju. Po wypraniu bielizny, miałam jeszcze prasować, ale do tego wziął inną aresztantkę p. Ewald, która po dwóch dniach wróciła do celi”64. Warto zwrócić uwagę, że obie zeznające były „używane" przez mężczyznę do sprzątania, prania i prasowania. Całkowicie wbrew jakiemukolwiek regulaminowi, „na dziko”. W takich sytuacjach komendant wykorzystywał seksualnie kobiety. Jeśli cokolwiek mu się nie podobało, swobodnie wymieniał aresztowane. Annę Ewald przetrzymywał w swoim pokoju dwa dni ${ }^{65}$. Jego władza była nieograniczona i nie było żadnej instancji, która mogłaby go powstrzymać czy uregulować relację pracodawca - pracownica. Gdyby incydent z biciem Zofii Lamparskiej nie zdarzył się przy świadkach, przemoc seksualna nigdy nie stałaby się przedmiotem śledztwa.

Po miesiącu - 1 sierpnia - ponownie przesłuchano oskarżonego, który nadal utrzymywał, że to Zofia Lamparska próbowała go uwieść i liczyła na romans z Frostem także po wyjściu $\mathrm{z}$ aresztu ${ }^{66}$. Powtórzył się zarzut o „nienaturalny stosunek seksualny”, do którego mężczyzna został zmuszony. Na pytania o gwałt komendant odpowiedział: „Gwałtu nie używałem oddała [Zofia - J.O.]

62 Tamże, k. 16-17.

63 Jeden ze strażników w obozie dla Niemców w Łambinowicach twierdził, że „gwałty Polaków na kobietach były na porządku dziennym”. W obozach pracy dla niemieckich cywilów o przemocy seksualnej w stosunku do więźniarek bardzo często decydowało również ogólne „rozpasanie”, chaos i brak dyscypliny wśród strażników. „Z próżniactwa strażnicy nakłaniają więźniarki do uległości. Był niedawno wypadek, kiedy więźniarka poskarżyła się o to” - pisał Michał Szarapow w raporcie dla Wojewódzkiego Urzędu Bezpieczeństwa Publicznego w Krakowie z inspekcji Centralnego Obozu Pracy w Jaworznie z czerwca 1945 r. Cyt. za: J. Ostrowska: Przemilczane..., s. 297-298.

64 AIPN, BU 813/57, k. 18-19.

6510 lipca Anna Ewald została wezwana raz jeszcze na przesłuchanie, w trakcie którego pytano ją o to, kto kazał jej zgolić owłosienie łonowe i czy otrzymała jakieś przedmioty od Frosta (koc i dwa fartuchy).

${ }^{66}$ Por. zeznanie Z. Frosta z 1.08.1945. AIPN, BU 813/57, k. 22-23, 25-26. 
się sama”67; „Nie. Stanowczo nie [brałem gwałtem Anny Ewald - J.O.]”68. W tym samym dniu zamknięto śledztwo i wystawiono postanowienie o pociągnięciu mężczyzny do odpowiedzialności karnej z artykułu 286 kk ${ }^{69}$, który dotyczył przekraczania kompetencji urzędniczej ${ }^{70}$. W sporządzonym akcie oskarżenia wpisano ten sam paragraf, zaznaczając, że komendant: „[...] dopuścił się gwałtu na kobietach przetrzymywanych w areszcie Pow. Urz. Bezp. Publ. W Sopocie"71, i uwzględniono dwa kolejne paragrafy: $291^{72}$ oraz $204^{73}$. Sprawa miała być rozpatrywana przez Sąd Okręgowy.

Dwa tygodnie później sporządzono nowy akt oskarżenia. Jego autorem był oficer śledczy Wojskowej Prokuratury Marynarki Wojennej, który przytoczył tylko artykuł $286 \mathrm{kk}$ : „[...] przez zmuszanie do nierządu aresztantek - Niemek i podawanie im do celi papierosów dopuścił się w celu korzyści osobistej przekroczenia władzy przy równoczesnym nie wypełnieniu swych obowiązków wynikających z przepisów służby więziennej działając przez to na szkodę interesu publicznego"74.

20 września - w trakcie posiedzenia niejawnego ${ }^{75}$ - Wojskowy Sąd Marynarski w Gdańsku wniósł o umorzenie postępowania z powodu braku wniosku pokrzywdzonych. Postępowanie anulowano, a areszt tymczasowy został uchylony. Mężczyznę zwolniono cztery dni później.

Wszystkie zeznania ofiar gwałtów składane od 30 czerwca przez kolejne dwa tygodnie przestały mieć jakiekolwiek znaczenie - nie traktowano ich jako wniosku pokrzywdzonych. Trudno powiedzieć, dlaczego sprawą nie zajął się Sąd Okręgowy, tylko Sąd Wojskowy i czy rzeczywiście ktokolwiek próbował wezwać na rozprawę Zofię Lamparską oraz Annę Ewald. Sprawę zamknięto. Zygmunt Frost został uznany za osobę niewinną, którą, dodatkowo, wbrew prawu przetrzymywano w areszcie. Jego los pozostaje nieznany.

67 Tamże, k. 7.

68 Tamże.

69 „\$1. Urzędnik, który przekraczając swą władzę lub nie dopełniając obowiązku, działa na szkodę interesu publicznego lub prywatnego, podlega karze więzienia do lat 5. $\$ 2$. Jeżeli sprawca działa w celu osiągnięcia korzyści majątkowej lub osobistej dla siebie lub innej osoby, podlega karze więzienia do lat 10" (Polski Kodeks Karny z 11. VII. 1932 r. Lwów 1932. Dostępne w Internecie: http://www.bibliotekacyfrowa.pl/Content/89357/PAd_11544.pdf [data dostępu: 1.11.2019]).

70 Por. AIPN, BU 813/57, k. 24, 28.

71 Tamże, k. 29.

72 „Jeżeli urzędnik dopuścił się jakiegokolwiek przestępstwa podczas urzędowania lub w związku z urzędowaniem, sąd może wymierzyć karę wyższą o połowę od najwyższego wymiaru kary, przepisanego za dane przestępstwo" (Polski Kodeks Karny z 11. VII. 1932 r....).

73 „\$1. Kto przemocą, groźbą bezprawną albo podstępem doprowadza inną osobę do poddania się czynowi nierządnemu lub do wykonania takiego czynu, podlega karze więzienia do lat 10. $\$ 2$. Ściganie następuje na wniosek pokrzywdzonego" (tamże).

74 AIPN, BU 813/57, k. 32-33.

75 Por. tamże, k. 38. 
„Lepiej nie mówić” - ponieważ świadectwa bohaterek tego tekstu były niewygodne nie tylko dla ich rodzin i bliskich, wywoływały również publiczne zgorszenie i często stawały się plamą na honorze nowych urzędników państwowych. Gwałty wojenne przemilczano, ponieważ wielokrotnie ofiary uznawano za niewiarygodne, niemoralne i dysfunkcyjne. Jeden z bohaterów filmu Wojciecha Smarzowskiego Róża (2011), repatriant z Wilna, którego żona została zgwałcona przez Rosjan, powtarzał w kółko zdanie: „[...] zepsuli ją, zepsuli mi moją Amelkę"76. To „zepsucie” przerażało ocalone kobiety, dlatego starały się zapomnieć o swojej tragedii. $\mathrm{W}$ ich przypadku koniec wojny nie oznaczał końca przemocy - nie tylko na poziomie symbolicznym. Brak uznania krzywd, powojenne naznaczenie i tabuizacja doświadczenia przemocy seksualnej stały się brzemieniem, które uniemożliwiało świadkowanie. Milczenie było najbezpieczniejsze. Nikogo nie obchodziło, że w trakcie wojny każdy przecież próbował przetrwać za wszelką cenę: „Wziął Erikę za rękę i rozkazał: »Chodź!« Nie pomógł żaden opór, wściekle zaciągnął ją do niewielkiego pokoju, gdzie widział łóźko. Nigdy w życiu nie zapomnę tej półtorej godziny, póki nie przyprowadził jej z powrotem. Niemal nieprzytomna oparła się o framugę, spojrzała na mnie i powiedziała tylko: »Przynajmniej żyję«"

\section{Bibliografia}

Aparat bezpieczeństwa w Polsce. Kadra kierownicza. T. 1: 1944-1956. Red. nauk. K. Szwagrzyk. Warszawa 2005.

Archiwum Instytutu Pamięci Narodowej, BU 813/57, k. 1-38.

Bergen D.L.: Sexual Violence in the Holocaust: Unique and Typical? In: Lessons and Legacies VII. The Holocaust in International Perspectives. Ed. D. Herzog. Evanston 2006, s. 179-200.

Brownmiller S.: Against Our Will. Men, Women and Rape. New York 1993.

Buryła S.: Tematy (nie)opisane. Kraków 2013.

Dziuban A.: Dekryminalizacja, praca, intersekcjonalność, uznanie: ramy ruchu pracownic i pracowników seksualnych w Europie. „Przegląd Socjologii Jakościowej” 2018, nr 14 (1), s. 12-44.

Eichhorn S., Kuwert Ph.: Das Geheimnis unseres Großmütter. Eine empirische Studie über sexualisierte Kriegsgewalt um 1945. Gießen 2011.

${ }^{76}$ Por. Róża. Reż. W. Smarzowski. Scen. M. Szczerbic. Polska 2011.

77 E.-M. von Kammecke: Ucieczka z koszalińskiego powiatu. W: Kobiety wypędzone. Opowieść o zemście zwycięzców. Red. M. Weber. Przeł. G. Kowalski. Zakrzewo 2008, s. 179. 
Gebhardt M.: Crimes Unspoken: The Rape of German Women at the End of the Second World War. Transl. N. Somers. Cambridge 2017.

Giza J.S., Morasiewicz W.: Poobozowe zaburzenia seksualne u kobiet jako element tzw. KZ-syndromu. „Przegląd Lekarski” 1974, nr 1, s. 65-75.

Giza J.S., Morasiewicz W.: Z zagadnień popędów w obozach koncentracyjnych. Przyczynek do analiz tzw. KZ-syndromu. „Przegląd Lekarski” 1973, nr 1, s. 29-41.

Hytrek-Hryciuk J.: „Rosjanie nadchodzą!”. Ludność niemiecka a żotnierze Armii Radzieckiej (Czerwonej) na Dolnym Ślasku w latach 1945-1948. Wrocław 2010.

Jan Paweł II: Homilia w czasie Mszy św. beatyfikacyjnej Karoliny Kózkówny, 10.06.1987. Dostępne w Internecie: http://www.nauczaniejp2.pl/dokumenty/wyswietl/id/739/ pos/16/haslo/ [data dostępu: 7.10.2020].

Kammecke E.-M. von: Ucieczka z koszalińskiego powiatu. W: Kobiety wypędzone. Opowieść o zemście zwycięzców. Red. M. Weber. Przeł. G. Kowalski. Zakrzewo 2008, s. $175-222$.

Kukla W.: Z dziejów poznańskiej neurochirurgii w latach 1952-1997. Poznań 1998.

Lóránd Z.: Exhibiting Rape, Silencing Women. Alaine Polcz in the House of Terror in Budapest. "East Central Europe" 2015, no 42, s. 321-342.

Magowska A., Bogusz H.: Z dziejów Sanatorium św. Elżbiety w Poznaniu i jego właścicielek. „Acta Medicorum Polonorum” 2014, R. 4, s. 63-78.

Okrafka-Nędza M.: Bóg liczy łzy kobiet. Prawdziwa historia kobiety zgwałconej przez sowieckiego „oswobodziciela”. Warszawa 2016.

Ostrowska J.: Kto istnieje, a kto nie, w polskim dyskursie II wojny światowej? „Res Publica Nova" 2009, nr 7, s. 62-68.

Ostrowska J.: Przemilczane. Seksualna praca przymusowa $w$ czasie II wojny światowej. Warszawa 2018.

Ostrowska J., Zaremba M.: Kobieca gehenna. „Polityka” 2009, nr 10 (2695), s. 64-66.

Paul Ch.: Zwangsprostitution. Staatlich Errichtete Bordelle im Nationalsozialismus. Berlin 1994.

Piech S.L.: Błogosławiona Karolina Kózka. „Folia Historica Cracoviensia” 2010, nr 15/16, s. 189-195.

Plüschke H., Schwerin E. von, Pless-Damm U.: Wypędzone. Historie Niemek ze Ślaska, z Pomorza i Prus Wschodnich. Trzy szczere świadectwa kobiet bezbronnych wobec zwycięzców. Przeł., wybór, oprac. E. Czerwiakowska. Warszawa 2013.

Polcz A.: Kobieta na froncie. Przeł. M. Roguska. „Literatura na Świecie” 2014, nr 3-4 (512-513), s. 339-374.

Polcz A.: Kobieta na linii frontu. Przeł. K. Wilamowska. Wybór G. Danyi. „Karta” 2018, nr 95, s. 101-115.

Polski Kodeks Karny z 11. VII. 1932 r. Lwów 1932. Dostępne w Internecie: http://www. bibliotekacyfrowa.pl/Content/89357/PAd_11544.pdf [data dostępu: 1.11.2019].

Posmysz Z.: Do wolności, do śmierci, do życia. Radzymin 1996.

Sommer R.: Das KZ-Bordell. Sexuelle Zwangsarbeit in nationalsozialistischen Konzentrationslagern. Paderborn 2010.

Zaremba M.: Wielka Trwoga. Polska 1944-1947. Ludowa reakcja na kryzys. Kraków 2012. 
JoAnNA OstrowsKa - dr nauk humanistycznych w zakresie historii. Jej zainteresowania badawcze koncentrują się na zjawisku przemocy seksualnej w czasie drugiej wojny światowej i historii zapomnianych ofiar Trzeciej Rzeszy. Opublikowała trzy książki: Przemilczane. Seksualna praca przymusowa w czasie II wojny światowej (2018), „Mój Führerze!”. Ofiary przymusowej sterylizacji na Dolnym Śląsku w latach 1934-44 (2019) i Oni. Homoseksualiści w czasie II wojny światowej (2021). Redaktorka merytoryczna oraz autorka posłowia do tomów: Heinza Hegera Mężczyźni z różowym trójkątem (2016) i Lutza van Dijka Cholernie mocna miłość (2017). 